\title{
CLINICAL AND BACTERIOLOGICAL EXAMINATIONS OF DOGS WITH TONSILLITIS
}

\author{
D. SYLEJMANI, I. MIFTARI, A. HAMIDI \& A. ROBAJ
}

Faculty of Agriculture and Veterinary, University of Prishtina, Kosovo

\section{Summary}

Sylejmani, D., I. Miftari, A. Hamidi \& A. Robaj, 2020. Clinical and bacteriological examinations of dogs with tonsillitis. Bulg. J. Vet. Med., 23, No 2, 229-236.

The aim of this study was to investigate the presence of tonsillitis in dogs and isolation of bacteria involved as well as their antimicrobial susceptibility. For this purpose from June 2015 to August 2017, 12 clinical cases of dogs with tonsillitis have been examined, and a total of 24 samples were collected. Diagnosis was based on anamnesis, clinical signs, haematology and biochemical tests and bacteriological analyses. The isolation and identification of bacteria was carried out according to conventional microbiological methods and biochemical tests, while the antimicrobial susceptibility of bacterial isolates was tested using the disk diffusion method. Escherichia coli was the most commonly isolated bacteria with isolation rate $35.0 \%$, followed by Streptococcus pyogenes $(27.50 \%)$, Staphylococcus aureus (20\%), Staphylococcus intermedius (10\%) and Pasteurella spp. (7.5\%). A high resistance to ampicillin, streptomicin and penicillin G was shown by E. coli, S. intermedius, $S$. pyogenes isolates. None of $S$. pyogenes, S. aureus, S. intermedius and Pasteurella spp., isolates was resistant to amoxicillin/clavulanic acid.

Key words: antimicrobial susceptibility, bacteria, canine tonsillitis

\section{INTRODUCTION}

Tonsillitis is often seen as an acute inflammation of the tonsils in conjunction with pharyngitis. Primary bacterial tonsillitis infections in cats and dogs are unusual (Ettinger \& Feldman, 2005). Tonsillitis is a term used to describe conditions when the tonsils are inflamed or infected. Its location at the crossing of the digestive and respiratory tracts plays a key role in immunity as this is the site where vast amounts of foreign antigens enter the body during feeding and breathing (Evans, 1993). Infection of the upper and lower airways follows either the movement of bacteria into otherwise sterile sites or the increase in bacterial burdens and compromised natural defenses leading to infection. Pathogenic bacteria include those that normally colonise the nasal cavities, tonsils and pharynx of otherwise healthy dogs (Blondeau, 2014). Chronic tonsillitis in young dogs is thought to rep- 
resent maturation of pharyngeal defense mechanisms. The tonsils are usually hyperaemic, mottled, enlarged and bulge from the crypts. Malaise, pyrexia, dysphagia and anorexia may also occur (Guilford, 1996; Quinn et al., 1997; Sturgess, 1999; Hitt et al., 2003). Bacteria isolated from dogs with tonsillitis are often of the same species as the normal flora found in the mouth and pharyngeal region (Quinn et al., 1997; Hitt et al., 2003). The commonest pathogenic bacteria isolated from diseased tonsils are Escherichia coli, Staphylococcus aureus, and haemolytic streptococci (Harvey \& O’Brien, 1983; Lipowitz et al., 1996). Pasteurella multocida was isolated in $92 \%$ of the dogs and $99 \%$ of the cats (Baldrias et al., 1988).

Identification of the major microorganisms with a pathogenic potential in the oral cavity of animals also plays an important clinical role such as to provide support towards adequate diagnosis and therapy in veterinary medicine (Braga et al., 2005). Fever and malaise are uncommon unless consequent to systemic infection. Gagging, followed by retching and soft cough, may result in expulsion of small amounts of mucus. In appetence, listlessness, salivation, and dysphagia are seen in severe tonsillitis (Läikkö et al., 2004). Tonsillar enlargement may range from protrusion just out of the crypts to a mass of sufficient size to cause dysphagia or inspiratory stridor (Lipowitz et al., 1996; Mufti, 2014). Tonsillitis usually is a sign of generalised or regional inflammatory disease. Squamous cell carcinoma, malignant melanoma, and lymphosarcoma commonly occur in canine tonsils and should be distinguished from tonsillitis. Tonsillar lymphosarcoma generally results in bilateral symmetric enlargement, whereas nonlymphoid neoplasia is usually unilateral (Mufti, 2014). Tonsillitis with severe and persistent clinical signs can be treated with broad spectrum antimicrobials for 10-14 days (Blondeau, 2014).

The purpose of this study was to determine clinical and bacteriological findings, haematological and biochemical parameters, and the antimicrobial resistance of isolated bacteria from tonsillitis in dogs.

\section{MATERIALS AND METHODS}

The study was carried out between June 2015 and August 2017. During this period, twelve dogs of different ages and sex were clinically examined (Table 1) after obtaining informed consent from their owners. The diagnosis of tonsillitis was based on the clinical manifestations and medical history. Additionally, haematological and chemical parameters of all dogs with tonsillitis were investigated. No antibiotic had been administered to the dogs before the tonsils swabs were obtained. In clinically examined dogs no comorbidities were observed.

Blood samples were collected from cephalic vein of each dog and immedi-

Table 1. Difference of animals with canine tonsillitis by age and sex

\begin{tabular}{|c|c|c|c|c|}
\hline Variable & Description & $\begin{array}{l}\text { Dogs } \\
\text { tonsillitis }\end{array}$ & with & $\begin{array}{l}\text { Tonsillitis occur- } \\
\text { rence } \%\end{array}$ \\
\hline \multirow[t]{2}{*}{ Age } & Up to 3 yrs & $7 / 12$ & & $58.0 \%$ \\
\hline & $4-7$ years & $5 / 12$ & & $42.0 \%$ \\
\hline \multirow[t]{2}{*}{ Sex } & Female & $4 / 12$ & & $33.3 \%$ \\
\hline & Male & $8 / 12$ & & $66.7 \%$ \\
\hline
\end{tabular}


ately dispensed in two tubes, one with EDTA and the other was plain to obtain serum. Haematological parameters were analysed in HumaCount $80^{\mathrm{TS}}$. Biochemical parameters were analysed in a biochemical analyzer (HumaLyzer Primus, Germany). Swabs for bacteriological culture $(n=24)$ were taken from surface of the tonsills through aseptic techniques under general anaesthesia, and transported to the laboratory under cooling conditions. The samples from the swabs were cultivated on sheep blood agar, MacConkey agar, eosin-methylene blue agar, mannitol agar and Muller-Hinton agar. Cultures were incubated aerobically for 24-48 hours at $37{ }^{\circ} \mathrm{C}$. After incubation, bacterial isolates were identified according to conventional microbiological methods (Quinn et al., 2011) and biochemical tests. The antimicrobial susceptibility of bacterial isolates to antimicrobial drugs was performed using disk diffusion method according to Clinical Laboratory Standards Institute; Performance standards for antimicrobial susceptibility testing (CLSI, 2012). Bacterial isolates were tested for the antimicrobial susceptibility using following disks: gentamicin $(10 \mu \mathrm{g})$, ampicillin $(10 \mu \mathrm{g})$, amoxicillin/ clavulanic acid $(30 \mu \mathrm{g})$, enrofloxacin $(5 \mu \mathrm{g})$, lincomycin $(15 \mu \mathrm{g})$ penicillin $\mathrm{G}$ (10 IU), and streptomycin $(10 \mu \mathrm{g})$. All statistical results were obtained using MINITAB software version 17.

\section{RESULTS}

In this study, regarding the age, the frequency of canine tonsillitis was higher in dogs between 1-3 years of age with 7/12 cases $(58.3 \%)$ followed by dogs between 4-7 years with $5 / 12$ cases $(41.7 \%)$. From total number of animals, 2 females belonged to the group age up to three years and 2 to the group between 4 and 7 years of age. Five males were up to 3 and 3 in the group from 4 to 7 years of age. The Chi-square test showed no statistical difference of the examined animals with canine tonsillitis according to age and sex. The affected breeds were Pekingese with 2 cases $(16.7 \%)$, Terrier with 2 cases (16.7\%), English Mastiff with 1 case $(8.3 \%)$, English Setter with 1 case $(8.3 \%)$, Illyrian Shepherd with 2 cases $(16.7 \%)$, cross-breed dogs with 2 cases (16.7\%), German Shorthaired Pointer with 1 case (8.3\%), and English Foxhound with 1 case $(8.3 \%)$. The main observed clinical signs were depression, anorexia, thirst, sporadic vomiting, and caudal oral pain (Table 2).

Table 2. Main symptoms of clinical manifestation of dogs with tonsillitis

\begin{tabular}{ll}
\hline Clinical manifestation & $\begin{array}{c}\text { Number }(\%) \\
\text { of cases }\end{array}$ \\
\hline Caudal oral pain & $8 / 12(66.7 \%)$ \\
Lethargy and drowsiness & $6 / 12(50 \%)$ \\
Anorexia and vomiting & $5 / 12(41.7 \%)$ \\
State of depression & $3 / 12(25 \%)$ \\
Extra thirst & $4 / 12(33.3 \%)$ \\
\hline
\end{tabular}

The mean haematology and serum chemistry values (Table 3 ) were within the reference range for dogs (Kaneko et al., 2008; Weiss \& Wardrop, 2010; Latimer, 2011) with the exception of the WBC that were higher $(19.73 \pm 4.6,5.0-14.1)$, neutrophils $(90.4 \pm 4.41,58-85 \%)$, and basophils $(0.26 \pm 0.05,0-0.14)$.

Among the 12 positive cases in microbiological tests, mono-infections (with single bacterial species) were observed in 11 cases $(91.7 \%)$ and only one case $(8.3 \%)$ was a co-infection (Staphylococcus aureus +Staphylococcus intermedius). From the 24 swab samples, 40 bacterial isolates were isolated. Escherichia coli was the most commonly isolated bacteria 
Clinical and bacteriological examinations of dogs with tonsillitis

Table 3. Mean values of hematology and serum chemistry of 12 dogs with tonsillitis

\begin{tabular}{llll}
\hline Analyte & Mean $\pm \mathrm{SD}$ & Observation range & Reference range $(\mathrm{SI})$ \\
\hline $\mathrm{RBC}\left(\times 10^{12} / \mathrm{L}\right)$ & $5.0 \pm 0.4$ & $4.9-6.2$ & $4.95-7.87$ \\
$\mathrm{WBC}\left(\times 10^{9} / \mathrm{L}\right)$ & $19.73 \pm 4.6$ & $11.2-24$ & $5.0-14.1$ \\
$\mathrm{Hb}(\times 10 \mathrm{~g} / \mathrm{L})$ & $12.2 .4 \pm 24.1$ & $9.7-16.0$ & $11.9-18.9$ \\
$\mathrm{PCV}\left(\times 10^{-2} \mathrm{~L} / \mathrm{L}\right)$ & $33 \pm 0.5$ & $25-41$ & $35-57$ \\
Reticulocytes $(\%)$ & $0.15 \pm 0.06$ & $0-0.3$ & $0-1.0$ \\
Neutrophils $(\%)$ & $90.4 \pm 4.41$ & $80-94$ & $58-85$ \\
Segs $\left(\times 10^{9} / \mathrm{L}\right)$ & $8.2 \pm 2.7$ & $4.1-12$ & $2.9-2.0$ \\
Band $\left(\times 10^{9} / \mathrm{L}\right)$ & $0.5 \pm 0.2$ & $0.4-1.2$ & $0-0.45$ \\
Lymphocytes $\left(\times 10^{9} / \mathrm{L}\right)$ & $2.8 \pm 0.9$ & $0.5-3.7$ & $0.4-2.9$ \\
Monocytes $\left(\times 10^{9} / \mathrm{L}\right)$ & $0.6 \pm 0.4$ & $0.1-1.3$ & $0.1-1.4$ \\
Eosinophils $\left(\times 10^{9} / \mathrm{L}\right)$ & $1.4 \pm 0.22$ & $0-1.6$ & $0-1.3$ \\
Basophils $\left(\times 10^{9} / \mathrm{L}\right)$ & $0.26 \pm 0.05$ & $0-0.31$ & $0-0.14$ \\
Glucose $(\mathrm{mmol} / \mathrm{L})$ & $5.7 \pm 1.5$ & $4.0-9.1$ & $4.2-6.6$ \\
ALT $(\mathrm{U} / \mathrm{L})$ & $74.7 \pm 33$ & $25-112$ & $10-109$ \\
Bilirubin $(\mu \mathrm{mol} / \mathrm{L})$ & $5.17 \pm 3.4$ & $3.42-15.39$ & $0-5.1$ \\
Protein $(\mathrm{g} / \mathrm{L})$ & $67.3 \pm 10.1$ & $53-81$ & $54-75$ \\
Urea nitrogen $(\mathrm{mmol} / \mathrm{L})$ & $2.5 \pm 1.8$ & $1-6$ & $2.9-10.0$ \\
Phosphorus $(\mathrm{mmol} / \mathrm{L})$ & $0.82 \pm 0.27$ & $0.4-1.5$ & $0.9-1.7$ \\
Sodium $(\mathrm{mmol} / \mathrm{L})$ & $137.6 \pm 5.9$ & $127-146$ & $142-152$ \\
Chloride $(\mathrm{mmol} / \mathrm{L})$ & $121.4 \pm 2.4$ & $118-125$ & $110-124$ \\
LDH $(\mathrm{U} / \mathrm{L})$ & $161.2 \pm 60$ & $80-260$ & $0-236$ \\
Magnesium $(\mathrm{mmol} / \mathrm{L})$ & $0.5 \pm 0.08$ & $0.4-0.65$ & $0.7-1.0$ \\
pH & $7.39 \pm 0.01$ & $7.38-7.4$ & $7.32-7.42$ \\
\hline
\end{tabular}

Table 4. Number of bacterial isolates and isolation rate of samples from canine tonsillitis

\begin{tabular}{lccc}
\hline Bacteria & No of isolates & Isolation rate (\%) & 95\% confidence limits \\
\hline Escherichia coli & 14 & 35.0 & $20.62-51.68$ \\
Streptococcus pyogenes & 11 & 27.5 & $14.60-43.88$ \\
Staphylococcus aureus & 8 & 20 & $9.05-35.64$ \\
Staphylococcus intermedius & 4 & 10 & $2.79-23.66$ \\
Pasteurella spp. & 3 & 7.5 & $1.57-20.38$ \\
\hline Total & 40 & 100.00 & \\
\hline
\end{tabular}

with isolation rate $35.0 \%$, then came Streptococcus pyogenes $(27.5 \%)$, Staphylococcus aureus (20\%), Staphylococcus intermedius (10\%) and Pasteurella spp. $(7.5 \%)$ as shown in Table 4.

Antimicrobial susceptibility tests were performed on a total of 40 bacterial isolates. A very high resistance to streptomycin (64\%), ampicillin (57\%) and penicillin G (57\%) was exhibited by Es- cherichia coli. Streptococcus pyogenes isolates were also more resistant to streptomycin (54\%), ampicillin (46\%) and penicillin G $(46 \%)$. Almost the same results were found and for $S$. intermedius isolates. S. aureus isolates were found to be resistant to penicillin $\mathrm{G}(50 \%)$ and lincomycin $(45.5 \%)$. The greatest resistance was demonstrated by Pasteurella spp., especially against streptomycin (66.7\%). 
D. Sylejmani, I. Miftari, A. Hamidi \& A. Robaj

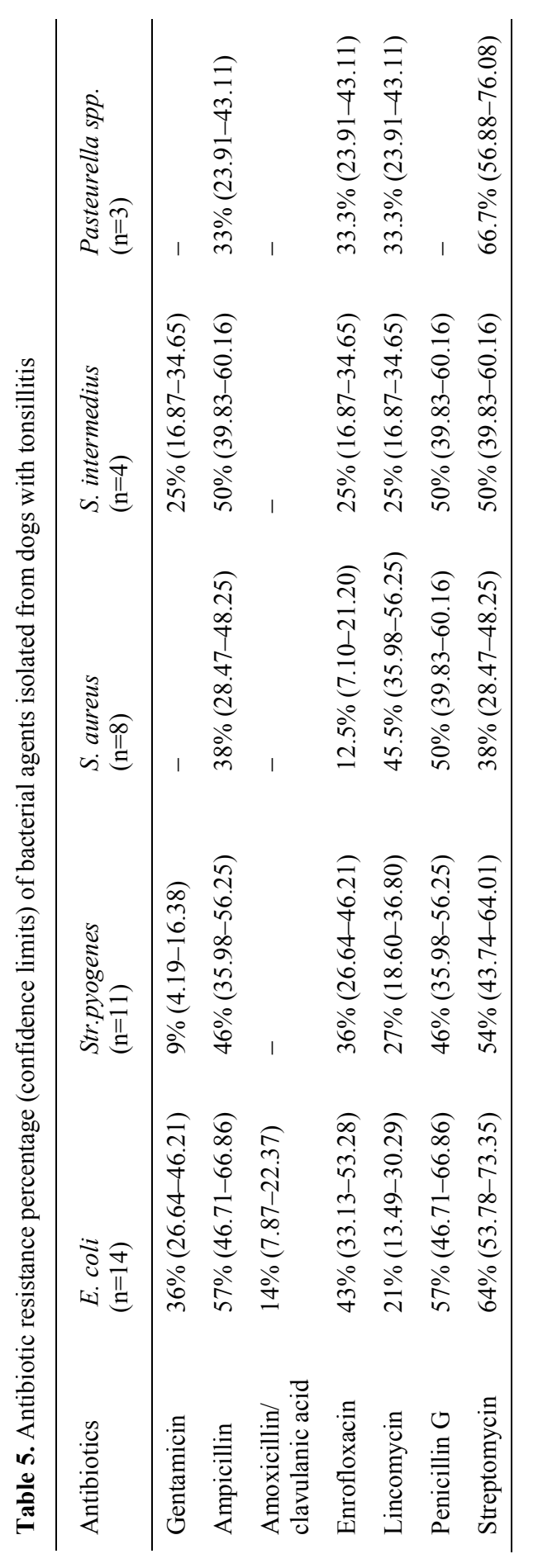

BJVM, 23, No 2 
All bacterial isolates showed sensitivity to the same antibiotic, that is amoxicillin/clavulanic acid (Table 5).

\section{DISCUSSION}

Tonsillitis are caused by various microbial agents but only the bacterial implications were considered in our study. The results of this study showed that 12 diseased dogs examined resulted with canine tonsillitis. The presence of tonsillitis at different age of dogs is almost close (Mufti, 2014), but our data shows that there was no statistical difference of the examined animals with canine tonsillitis based on to age and sex.

Escherichia coli was the most commonly isolated bacteria involved in canine tonsillitis as a single infection with 5 cases (41.7\%), Streptococcus pyogenes with 3 cases (25\%), Staphylococcus aureus 1 case $(8.3 \%)$, Staphylococcus intermedius with 1 case $(8.3 \%)$, Pasteurella spp., with 1 case $(8.3 \%)$, and as a co-infection $S$. aureus $+S$. intermedius were isolated with one case $(8.3 \%)$. The findings in this study about the most frequent bacterial isolates are almost similar to those previously reported by other authors. The microorganisms most often associated with tonsillitis are Escherichia coli, Staphylococcus albus, Staphylococcus aureus, Streptococcus and Pasteurella (Lipowitz et al., 1996; Guilford, 1996; Quinn et al., 1997; Hitt et al., 2003).

Canine tonsillitis infection and treatment is an important part of veterinary practice. The antimicrobial susceptibility tests carried out in this study show in general a high resistance for E. coli, Streptococcus intermedius, Streptococcus pyogenes to ampicillin, streptomicin and penicillin G. None of Streptococcus pyogenes, $S$. aureus, $S$. intermedius and Pasteurella spp., isolates were resistant to amoxicillin/clavulanic acid which shows the efficacy of this antibiotic in treatment of tonsillitis. In addition, none of Pasteurella spp. isolates were resistant to gentamicin and streptomycin. The present study revealed higher sensitivity for all bacterial isolates to the same antibiotic as is amoxicillin/clavulanic acid. During the last 50 years, the number of companion animals in modern society has substantially increased and a change in their social role has occurred. Attention to their welfare has increased as a consequence of the close contact between owners and their pets. Humans may acquire antimicrobial-resistant bacteria or the corresponding resistance genes not only from food-producing animals but also via contact with their companion animals. MRSA, methicillin-resistant Staphylococcus pseudintermedius (MRSP), ESBL/ AmpC-producing enterobacteriaceae and MDR non-fermenting Gram-negative bacteria have emerged in healthy and sick dogs and cats, implying a potential risk of transmission of these bacteria to humans from infected or colonised companion animals (Weese \& van Duijkeren, 2010; Wieler et al., 2011; Ewers et al., 2014). In addition, there is the possibility of transfer of resistance genes.

In conclusion, this study indicated that the most commonly isolated bacterial agents from tonsillitis in dogs were $E$. coli, Streptococcus pyogenes and Staphylococcus aureus and their isolates showed resistance to ampicillin, streptomycin and penicillin G. Otherwise, all bacterial isolates showed the highest sensitivity to the same antibiotic as is amoxicillin/clavulanic acid. Therefore, the data of this study will be necessary to assess the risks in the context of applications for new veterinary antimicrobials for companion animals for which risk levels are estimated as acceptable for public health. 


\section{ACKNOWLEDGEMENTS}

Authors are thankful to the Faculty of Agriculture and Veterinary for providing necessary research facilities.

\section{REFERENCES}

Baldrias, L., A. J. Frost \& D. O’Boyle, 1988. The isolation of Pasteurella-like organisms from the tonsillar region of dogs and cats. Journal of Small Animal Practice, 29, 63-68.

Blondeau, J. M., 2014. Steps to antimicrobial therapy. Strategies to optimize therapy and minimize resistance when treating bacterial infections. $2^{\text {nd }}$ edn, North American Compendiums Inc, pp. 121-127.

Braga, C. A. B., C. M. F Resende, A. C. N. R Pestana, L. S. Carmo, J. E. Costa, L. A. F. S. Silva, L. N. Assis, L. A. Lima, L. M. Farias \& M. A. R. Carvalho, 2005. Isolamento e identificação da microbiota periodontal de cães da raça Pastor Alemão. Ciencia Rural, 35, 385-390.

CLSI/NCCLS, 2012. Clinical Laboratory Standards Institute. Performance standards for antimicrobial susceptibility testing. $15^{\text {th }}$ Informational Supplement. CLSI/NCCLS document. Pennsylvania, USA.

Ettinger, S. J. \& E. C. Feldman, 2005. Textbook of Veterinary Internal Medicine, $6^{\text {th }}$ edn, W.B. Saunders Company.

Evans, H. E., 1993. Miller's Anatomy of the Dog. $3^{\text {rd }}$ edn, Saunders, Philadelphia.

Ewers, C., A. Bethe \& I. Stamm, 2014. CTXM-15-D-ST648 Escherichia coli from companion animals and horses: Another pandemic clone combining multiresistance and extraintestinal virulence? Journal of Antimicrobial Chemotherapy, 69, 12241230.

Guilford, W. G., 1996. Diseases of the oral cavity and pharynx. In: Strombeck's Small Animal Gastroenterology, $3^{\text {rd }}$ edn, eds W. G. Guilford, S. A. Center, D. R. Strom- beck, D. A. Williams, D. J. Meyer, WB Saunders, pp. 189-201.

Harvey, C. \& J. O’Brien, 1983. Disorders of the oropharynx and salivary glands. In: Textbook of Veterinary Internal Medicine, $2^{\text {nd }}$ edn, ed S. J. Ettinger, WB Saunders, Philadelphia, p. 566.

Hitt, M. E., D. L. Zoran \& L. J. Debowes, 2003. Diseases of the oral cavity and pharynx. In: Handbook of Small Animal Practice, $4^{\text {th }}$ edn, eds R. V. Morgan, R. M. Bright, M. S. Swartout, Saunders, Philadelphia, pp. 298-317.

Kaneko, J. J., J. W. Harvey \& M. L. Bruss, 2008. Clinical Biochemistry of Domestic Animals, $6^{\text {th }}$ edn, Academic Press.

Läikkö, T., M. L. Danielsson-Tham, W. V. Tham, V. Båverud, S. Fridén \& A. G. Hansson, 2004. Canine tonsillitis associated with Listeria monocytogenes. The Veterinary Record, 54, 732.

Latimer, K. S., 2011. Duncan \& Prasse's Veterinary Laboratory Medicine: Clinical $\mathrm{Pa}$ thology, $5^{\text {th }}$ edn, Wiley-Blackwell.

Lipowitz, A., D. Caywood, C. Newton \& A. Schwartz \& C. Cann, 1996. Complications in Small Animal Surgery: Diagnosis, Management, Prevention, Williams \& Wilkins, Baltimore, pp. 165-166.

Mufti, B. A., 2014. Isolation of the bacterial causes of tonsillitis in dogs. Iraqi Journal of Veterinary Sciences, 1, 27-29.

Quinn, P. J., W. J. C. Donnelly, M. E. Carter, B. K. J. Markey, P. R. Torgerson, R. M. S. Breathnach \& D. Maguire, 1997. Digestive system. In: Microbial and Parasitic Diseases of the Dog and Cat. London, W.B. Saunders, pp. 21-86.

Quinn, P. J., B. K. Markey, F. C. Leonard, P. Hartigan, S. Fanning \& E. S. Fitzpatrick, 2011. Veterinary Microbiology and Microbial Disease, $2^{\text {nd }}$ edn, Wiley-Blackwell, pp. 143-149.

Sturgess, C. P., 1999. Diseases of the alimentary tract. In: Textbook of Small Animal Medicine, ed J. K. Dunn, W.B. Saunders, London, pp. 371-447. 
Weese, J. S. \& E. van Duijkeren, 2010. Methicillin-resistant Staphylococcus aureus and Staphylococcus pseudintermedius in veterinary medicine. Veterinary Microbiology, 140, 418-429.

Weiss, D. J. \& K. J. Wardrop, 2010. Schalm's Veterinary Hematology, $6^{\text {th }}$ edn, WileyBlackwell, Blackwell Publishing Ltd, pp. 799-820.

Wieler, L. H., C. Ewers S. Guenther, B. Valther \& A. Lübke-Becker, 2011. Methicillin-resistant staphylococci (MRS) and extended-spectrum $\beta$-lactamases (ESBL)producing Enterobacteriaceae in companion animals: Nosocomial infections as one reason for the rising prevalence of these potential zoonotic pathogens in clinical samples. International Journal of Medical Microbiology, 301, 635-641.

Paper received 11.07.2018; accepted for publication 02.10 .2018

\section{Correspondence:}

Assoc. Prof. Avni Robaj, PhD

Faculty of Agriculture and Veterinary,

University of Prishtina,

Str. Bill Clinton, n. n., 10000, Kosovo

e-mail:avni.robaj@uni-pr.edu 